\title{
DEVELOPMENT OF PYROCHEMICAL REPROCESSING OF THE SPENT NUCLEAR FUEL AND PROSPECTS OF CLOSED FUEL CYCLE
}

\author{
R. Tulackova, K. Chuchvalcova-Bimova, M. Precek, \\ M. Marecek and Jan Uhlir \\ Fluorine Chemistry Department - Nuclear Research Institute Rez plc, \\ 25068 Husinec - Rez \\ tulackova@ujv.cz
}

\begin{abstract}
DEVELOPMENT OF PYROCHEMICAL REPROCESSING OF THE SPENT NUCLEAR FUEL AND PROSPECTS OF CLOSED FUEL CYCLE. Molten-Salt Reactor (MSR) is a design of an advanced reactor system from the GEN IV family working in thermal or epithermal neutron spectrum and using thorium or transuranium fuel in the form of molten fluorides. It is based on the experience with the development of the molten-salt reactor technology in the Oak-Ridge National Laboratory in the United States.

The MSR fuel cycle with integrated reprocessing represents one of the potential ways both for significant decrease of total amount of radioactive wastes for final deposition and for utilization of nuclear energy for electricity and heat production as effectively as possible.

There are two pyrochemical reprocessing techniques studied in NRI Rez plc which are considered to be applied both for reprocessing of already existing spent fuel and for preparation and „on-line“ reprocessing of MSR fuel: (i) the Fluoride Volatility Method (FVM), which performs chemical conversion of spent thermal oxide fuel components into fluorides and their consequent separation by means of their different volatility, thermal stability and chemical affinity to various sorbents; and (ii) electrochemical separation of the actinides (Ans) and fission products (FP), represented mainly by lanthanides (Lns), from each other by electrolytic deposition method on solid cathode in molten fluoride media.
\end{abstract}

Keywords : Pyrochemical Reprocessing, Spent Nuclear Fuel, Closed Fuel Cycle, Molten Salt Reactor

\section{INTRODUCTION}

Molten-Salt Reactors are usually characterized as non-classical nuclear reactors due to the liquid nature of their fuel - molten mixture of fluoride salts [1]. The melt circulates between the reactor core and the heat exchanger of the primary circuit (the secondary circuit is formed as well by a molten salt and prevents the contamination of the tertiary circuit which involves the turbine). The fissile material is dissolved in a carrier salt that at once serves as fuel and as a heat-carrier liquid. The technology of MSR was successfully tested in 1960s by the Molten-Salt Reactor Experiment (MSRE) in the OakRidge National Laboratory in the USA. [2]

The Molten-Salt Transmutation Reactor (MSTR) utilizes a significant advantage of liquid fuel - the possibility of continual reprocessing of the circulating fuel mixture that makes possible to repeatedly return the unconsumed neptunium, plutonium, americium and curium back to the 
reactor while separating from the liquid fuel the products of their fission, which negatively influence the neutron balance of the reactor.[3] For such "on-line" reprocessing technology, pyrochemical separation processes are considered to be convenient. There are two main studied pyrochemical methods in the world: molten salt/liquid metal reductive extraction and electrochemical separation. Their combination is supposed to be used for reprocessing of the spent fuel generated by the MSRs.

Apart from the technology of reprocessing the fluoride fuel, a key step of the system is the preparation of fresh fuel for the MSTR out of spent nuclear fuel from classical reactors. The best choice for this operation is the Fluoride Volatility Method (FVM) that enables the mutual separation of uranium from plutonium, minor actinides and majority of fission products.

\section{FLUORIDE VOLATILITY METHOD - FRONT-END OF MSTR FUEL CYCLE}

The function of the FVM is chemical conversion of spent fuel components from oxide form into fluoride form and their consequent separation by means of thermal decomposition, volatility and chemical affinity to solid fluoride sorbents. The separation process is based on specific properties of uranium, neptunium and plutonium that - under certain conditions - form volatile hexafluorides, whereas the majority of fission products (e.g. all lanthanides) and the transplutonides (Am, Cm) constitute non-volatile fluorides. The volatile fluorination products have also distinct boiling points therefore it is possible to further separate them by fractional distillation. [4]

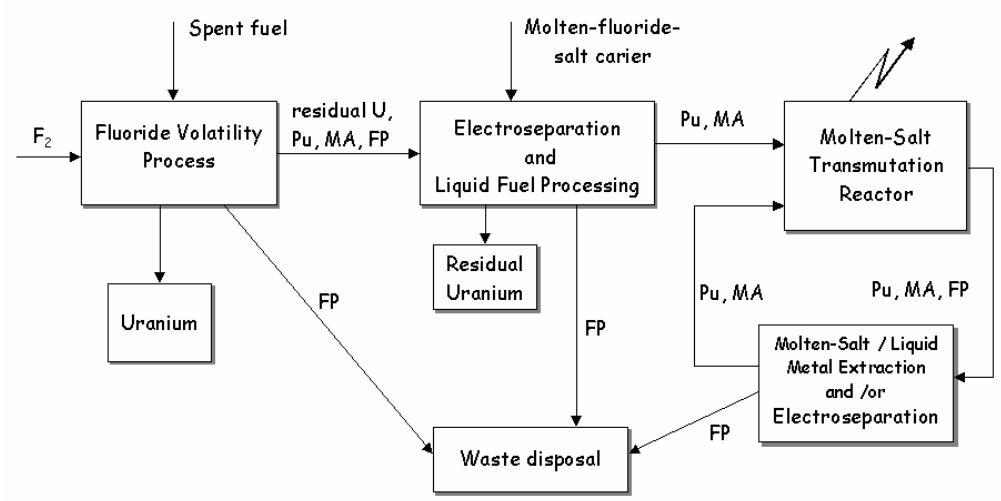

Fig. 1. Pyrochemical processes in MSTR fuel cycle. 
The application of FVM (which was originally developed in connection with fast reactor fuel cycle) as the key reprocessing technology for the Front-end of MSTR fuel cycle started to be considered in the end of 1990s when the technologies of Partitioning \& Transmutation came into focus as a possible solution for final management of spent nuclear fuel. However the FVM has not yet acquired industrial maturity and is so far studied on the level of semi-industrial technological tests. In the MSTR fuel cycle the purpose of FVM shall be the separation of spent fuel into three parts - purified uranium (in form of $\mathrm{UF}_{6}$ for the needs of classical and fast reactors), volatile products of fission products fluorination and a part containing the possible uranium residues, plutonium, minor actinides and fission products that are not forming volatile fluorides. The last part is an input material for the processes of electroseparation and preparation of fresh fuel for the MSTR, where it is separated into three streams again (see Fig.1).

The FVM consists of four operations:

1. Removal of spent nuclear fuel cladding

2. Conversion of the spent fuel into a powder form with desired granulometry suitable for fluorination

3. Fluorination of the powder fuel

4. Mutual separation of the formed volatile products

Flame fluorination of spent oxide fuel is the principal operation of the whole method. Fluorine is a very aggressive element capable of combining with almost every other elements not excluding heavier noble gases. Being a stronger oxidative agent than oxygen it can expel oxygen out of even very stable oxides. This ability can be utilized in fluorination of oxide fuels. The major component of LWR spent fuel is $\mathrm{UO}_{2}(\sim 95 \%$ mass). This compound reacts with fluorine gas forming $\mathrm{UF}_{6}(\mathrm{~g})$ and $\mathrm{O}_{2}(\mathrm{~g})$ [0]. The reaction is exothermic and runs autonomously from the point of ignition at approx. $250^{\circ} \mathrm{C}$, the maximum reached temperature achieves $1700^{\circ} \mathrm{C}$. A certain fluorine surplus is desirable because the reaction is heterogeneous - between gas and solid phases. Fluorination of actinides yields non-volatile trifluorides of $\mathrm{Am}$ and $\mathrm{Cm}$ and volatile hexafluorides - stable $\mathrm{UF}_{6}$ with $\mathrm{NpF}_{6}$ and unstable $\mathrm{PuF}_{6}$ (sublimation points of which are $56,5{ }^{\circ} \mathrm{C}$ for $\mathrm{UF}_{6}, 55,2{ }^{\circ} \mathrm{C}$ for $\mathrm{NpF}_{6}$ and $62,2{ }^{\circ} \mathrm{C}$ for $\mathrm{PuF}_{6}$ ). Soon after their formation, the gaseous fluorides are condensed in a series of condensers arranged in a descending temperature cascade, which allows separating of higher-boiling $\left(\mathrm{RuF}_{5}\right)$ and lower-boiling components $\left(\mathrm{SeF}_{6}, \mathrm{TeF}_{6}\right)$ from the uranium hexafluoride.

The thermal instability of $\mathrm{PuF}_{6}$ is one of the main methods of separating plutonium from uranium. A second possibility would be to employ sorption-desorption mechanisms on solid fluorides of sodium $\mathrm{NaF}$ and magnesium $\mathrm{MgF}_{2}$. At $100^{\circ} \mathrm{C}$ all the three fluorides are completely adsorbed. But although $\mathrm{UF}_{6}$ and $\mathrm{NpF}_{6}$ can be quantitatively desorbed by gaseous 
fluorine at $400^{\circ} \mathrm{C}$, the desorption of $\mathrm{PuF}_{6}$ is not possible, because the sorption-produced complex of plutonium $\mathrm{PuF}_{4} .3 \mathrm{NaF}$ is thermally stable even in fluorine atmosphere. Partial separation of neptunium from uranium is possible only by sorption of $\mathrm{NpF}_{6}$ on $\mathrm{MgF}_{2}$. Although a satisfying solution of the separation of neptunium in the frame of FVM has not been yet identified, the possibilities of the process have not yet been fully used up.

The final purification of $\mathrm{UF}_{6}$ from $\mathrm{MoF}_{6}, \mathrm{TcF}_{6}, \mathrm{IF}_{5}$ and $\mathrm{SbF}_{5}$ can be performed by fluoride distillation. The distillation of $\mathrm{UF}_{6}$ is usually performed in the temperature region of 75 to $90^{\circ} \mathrm{C}$ at pressure between $200-300 \mathrm{kPa}$, where the $\mathrm{UF}_{6}$ forms a liquid phase essential for the distillation process.

\section{R\&D OF FLUORIDE VOLATILITY METHOD IN NRI REZ PLC}

The last two operations of FVM (fluorination and separation) are being developed at the Fluorine Chemistry Department of NRI Rez plc, where a technological line called FERDA (Fluoride Experimental Research and Development Assembly) has been brought into operation in 2003. The line serves for process studies with non-radioactive and low-radioactive substances and therefore it can be used outside hot-cells. A view on the line FERDA is in Fig.2. Its basic components are the flame fluorinator, three condensers a sorption column, distillation column with two adjacent condensers and storage tanks for waste gases. The primary construction materials of the line are nickel alloys because of their outstanding corrosion resistance to fluorine.

Contemporary activities comprise studies of flame fluorination of uranium oxide and simulated spent oxide fuel and the performance of condensers. Besides theoretical calculations under various conditions (composition, temperature, pressure) there were some adjustments performed on the condensers. The study of the kinetics of the flame reaction is very problematic because of the high temperature reached in the flame prohibit the employment of standard techniques used in for studies of heterogeneous reactions (gas - solid phase). During the year 2006 the performance of the fluorinator heating system has been leveled up, so that reaching the powder self-ignition temperature has become easier.

In December 2006 the experiments with fluorination of uranium oxides have been supplemented by fluorination of oxide mixture simulating spent nuclear fuel from VVER type light-water reactors. As this was the first experiment the $4 \%$ of uranium has been replaced by non-volatile fluoride forming elements in composition $50 \% \mathrm{Y}_{2} \mathrm{O}_{3}, 25 \% \mathrm{Nd}_{2} \mathrm{O}_{3}, 20 \% \mathrm{CeO}_{2}$ a $5 \%$ $\mathrm{Sm}_{2} \mathrm{O}_{3}$. The experiments with volatile fluoride forming elements are going to be tested later, as they would be probably connected with tests of pre-separation in condensers and consequently the functionality of the distillation process. 


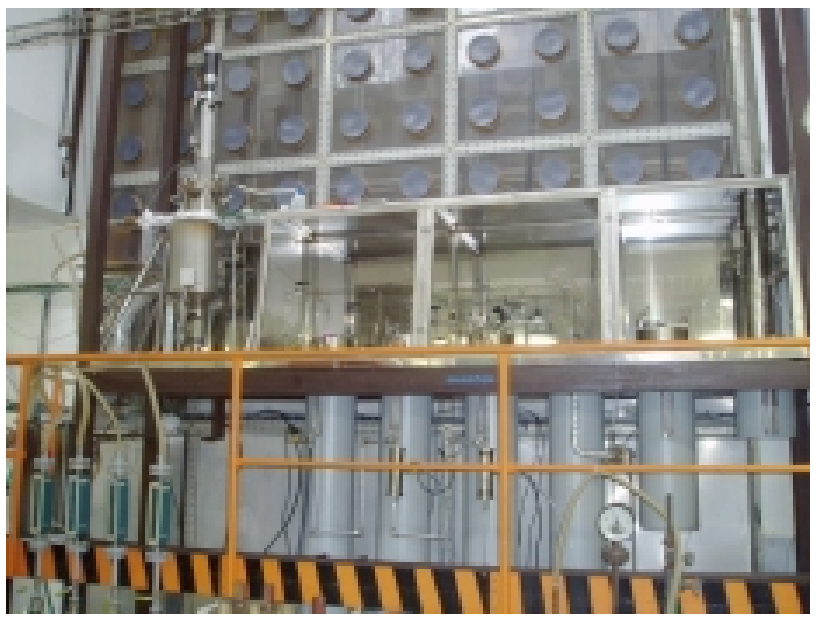

Fig. 2. FERDA line in NRI Rez plc.

\section{ELECTROCHEMICAL SEPARATION}

The main objective of the presented work was to appraise separation possibilities of electrochemical separation of the selected actinides (U, Th) and lanthanides ( $\mathrm{Nd}, \mathrm{Gd}, \mathrm{Eu}, \mathrm{Pr}, \mathrm{La})$ in molten fluoride salt media. Due to the lack of thermodynamic data, the electrochemical properties needed for the appraisal were determined by experimental measurements. They were focused both on determination of the exploitable potential range of the used fluoride carrier melts and mainly on determination of the particular deposition potentials of the selected studied species. Their electrochemical behavior was investigated by the Linear Sweep Cyclic Voltammetry Method in molten eutectic mixtures of LiF-NaF-KF at $530^{\circ} \mathrm{C}, \mathrm{LiF}_{-} \mathrm{CaF}_{2}$ at $850^{\circ} \mathrm{C}$ and $\mathrm{LiF}-\mathrm{BeF}_{2}$ at $540^{\circ} \mathrm{C}$ under inert atmosphere of highly pure argon. The experimental set-up, specially designed reference electrode based on $\mathrm{Ni} / \mathrm{Ni}^{2+}$ red-ox couple enabling measurements in molten fluoride media are described and the reached results with appraisal of the An/Ln separation possibilities in the studied molten fluorides are presented.

\section{PRELIMINARY OPERATION AND TECHNICAL BACKGROUND}

\section{Selection and preparation of the melt}

For electrochemical studies, it is necessary to select a suitable carrier melt as electrolyte, that should fit above all the following properties: Low melting point, high solubility of studied compounds, high electrochemical stability and appropriate physical properties (electrical conductivity, 
viscosity etc.). In case the same melt should be used also as a carrier melt for MSTR fuel, also high radiation resistance, low cross-section and other properties dealing with behavior in the active zone should be considered.

The eutectic mixtures of LiF-NaF-KF (acronym FLINAK, 46.5-11. 5-42.0 in molar \%, melting point $\left.454^{\circ} \mathrm{C}\right), \mathrm{LiF}_{-} \mathrm{CaF}_{2}$ (79.5-20.5\%, melting point $766^{\circ} \mathrm{C}$ ) and $\mathrm{LiF}-\mathrm{BeF}_{2}$ (acronym FLIBE, $67.2-32.8$ molar \%, melting point $\left.456^{\circ} \mathrm{C}\right)[1]$ were selected as carrier electrolytes for the realized electrochemical measurements. The first two mixtures will probably not be applied as a carrier fuel salt of the MSR primary circuit, but they represent the suitable media for basic appraisal of separation possibilities of An/Ln in molten fluoride salts.

The raw materials constituting used mixtures except $\mathrm{BeF}_{2}$ were desiccated before the melt preparation under vacuum at step-by-step increasing temperature $60-90-150-250^{\circ} \mathrm{C}$, each step lasted at least 24 hours.

\section{Experimental equipment}

\section{Experimental set-up - Electrochemical cell and glove box}

The experimental set-up consists of electrochemical cell described beneath, either high power potentiostat Wenking HP 96-20 coupled by analogue scan generator Wenking MVS 98 (both made by Bank Elektronik Intelligent Controls $\mathrm{GmbH}$, Germany) or of HEKA potenciostat. The apparatuses are connected to PC for a control of the electrochemical processes and simultaneously the PC provides data acquisition and processing by softwares developed by the potentiostat producers.

The electrochemical cell is placed in electrolyser that was originally designed and produced. Its body is composed of a nickel vessel closed by removable flange, where electrode holders for reference, working and current electrodes are built in. The auxiliary parts are also located on the flange: An argon inert atmosphere inlet and outlet equipped with a control valve with a manometer and a thermocouple probe. The construction of electrochemical cell and electrode holders provides work under an inert atmosphere or vacuum even during shifting of electrodes due to the special original arrangement of gaskets.

The electrolyser is heated by a resistance oven providing homogenous thermal field up to the temperature $1000^{\circ} \mathrm{C}$. The whole apparatus is placed inside a glove-box with nitrogen atmosphere, where a content of moisture is monitored and usually is in the range of $10-20 \mathrm{ppm}$.

\section{Reference electrode}

Two types of reference electrode (RE) were used during the experiments. They take advantage of Nernstian behavior of $\mathrm{Ni} / \mathrm{Ni}^{2+}$ red-ox 
couple [7] and were developed to provide reproducible electrochemical measurements in molten fluoride salt medium. The particular design is similar to the reference electrode reported by H. R. Bronstein et al. [8], but the construction was significantly simplified.

The RE's main body is produced from pyrolitic boron nitride, grade HIP, filled with mixture of $\mathrm{NiF}_{2}$ (1.0 molar solution) with the same carrier melt as the measured one and nickel wire is tightly held by a holder, passed through a nut (both are made from pure nickel metal as well) and immersed into the melt.

The main difference between the RE two types resides in the part providing electric charge transfer between the inside and outside of the electrode. For the first RE type it was realized by capillary, whilst for the second type the $\mathrm{LaF}_{3}$ single crystal (doped by $\mathrm{EuF}_{3}$ ) as the ion selective membrane was applied. The realized experiments proved satisfactory potential stability of the electrode for short-term measurements.

\section{ELECTROCHEMICAL MEASUREMENTS}

In the following chapters, the basic results of electrochemical measurements are described, when the behaviour of each compound is compared in different studied melts, if available. However, the precise direct comparison of measured potential values is impossible due to the different potential of used reference electrodes $\left(\mathrm{Ni} / \mathrm{Ni}^{2+}\right.$ in FLINAK and $\mathrm{Ni} / \mathrm{Ni}^{2+}$ in LiF-CaF 2 ).

The Linear Potential Sweep Cyclic Voltammetry Method was used as the measurement technique with predominantly applied scan rate $50 \mathrm{mV} / \mathrm{s}$. Studies with different scan rates were also realized during experiments. The potentials stated in the following text are related to the potential corresponding to the used $\mathrm{Ni} / \mathrm{Ni}^{2+}$ reference electrode. The atmosphere of highly pure argon gas $(99.998 \%)$ was maintained in the electrochemical cell during all realized measurements and working temperature was kept in FLINAK at $530^{\circ} \mathrm{C}$, in $\mathrm{LiF}_{-} \mathrm{CaF}_{2}$ at $850^{\circ} \mathrm{C}$ and in FLIBE at $540^{\circ} \mathrm{C}$.

\section{Pure carrier melts}

All three mentioned pure carrier melts FLINAK, FLIBE and $\mathrm{LiF}_{-\mathrm{CaF}}$ were examined to determine their usable potential ranges and also to characterize possibly presented impurities, which would allow a correct interpretation of detected peaks corresponding to the studied elements. The cathodic limit is characterized by reduction of the most unstable compound constituting the melt and the particular shape of the voltammogram depends on working electrode material. Nevertheless, the evaluated potential limit is approximately the same for all studied materials. The found value for molybdenum working electrode, which was the most common working 
electrode material, is $-2.05 \mathrm{~V}$ for FLINAK, $-1.50 \mathrm{~V}$ for FLIBE and $-2.30 \mathrm{~V}$ and $\mathrm{LiF}-\mathrm{CaF}_{2}$.

However the melts were supposed to be electrochemically inactive in the potential area prior its decomposition, it was not confirmed by the experiments. A gradual current decrease was observed at more positive potential than the steep drop of voltammogram. The process is rather reversible and almost the same wave is formed during the back scan. Formation of a surface alloy by reduced metal with material of working electrode is the most probable explanation of the found fact, because an effect of presented impurities including moisture was experimentally challenged.

\section{Electrochemical characteristics of uranium and thorium species}

The mixtures containing 1.0 molar $\%$ of $\mathrm{UF}_{4}$ was used for electrochemical studies of uranium in all three studied carrier melts. Its electrochemical behaviour was found to be similar in each melt, when a twostep reduction up to uranium metal was observed. Both reactions seem to be quite well reversible and in case of FLINAK, measured voltammograms correspond well to theoretical assumptions and they are also in very good agreement with data published by Clayton et al. (1974) [4]. In case of LiF$\mathrm{CaF}_{2}$ melt, the ratio between maximums of current densities of the peaks does not correspond to the expected value 1:3, albeit the potential difference between the peaks is almost the same in both melts. The typical voltammograms of the systems see at Fig. 3 and Fig. 4.

Thorium behaviour was investigated only in the system FLINAK-ThF 4 (1.0 molar \%) with molybdenum working electrode. According to reached results, the mechanism of electrochemical reduction of thorium seems to be two-step reaction as well, while the reduction up to thorium metal takes place at almost the same potential like the decomposition of the carrier melt. A pair of peaks was recorded in the area of higher potential values, while the change of the current slope occurred just before the melt decomposition potential area. The anodic peak corresponding to stripping of deposited thorium metal was detected during the back scan after the peak belonging to oxidation of alkali metal reduced during the melt decomposition. The measured voltammograms qualitatively well agreed to the data published by Clayton et al. (1974) and the typical one is also at Fig. 3.

\section{Electrochemical characteristics of selected lanthanides}

Neodymium, gadolinium, europium, lanthanum and praseodymium (La and $\mathrm{Pr}$ were studied only in FLINAK) were selected as the representatives of the group of lanthanides and all of them were added into the carrier melts in a form of trifluorides. On contrary to the case of uranium, their electrochemical behaviour significantly depends on used carrier melt. 
In case of all measured lanthanides in FLINAK on molybdenum working electrode it was impossible to detect reduction to $\mathrm{Nd}, \mathrm{Gd}$, $\mathrm{La}$ and $\mathrm{Pr}$ metals, because these reactions are hindered by the melt decomposition. Reduction to europium metal was observed, but similarly like in case of thorium very close to the melt decomposition.

In $\mathrm{LiF}_{-} \mathrm{CaF}_{2}$, one-step reduction mechanism was observed on molybdenum electrode in for $\mathrm{Nd}, \mathrm{Gd}$ with just directly opposite reduction possibilities comparing to FLINAK. Peaks corresponding to neodymium and gadolinium reduction were detected in $\mathrm{LiF}-\mathrm{CaF}_{2}$, whilst no electrochemical action was observed in case of europium. The comparison of neodymium and gadolinium voltammograms in both melts (they have not been studied in FLIBE yet) measured on molybdenum working electrode see at Fig. 5 and that of europium at Fig. 6.
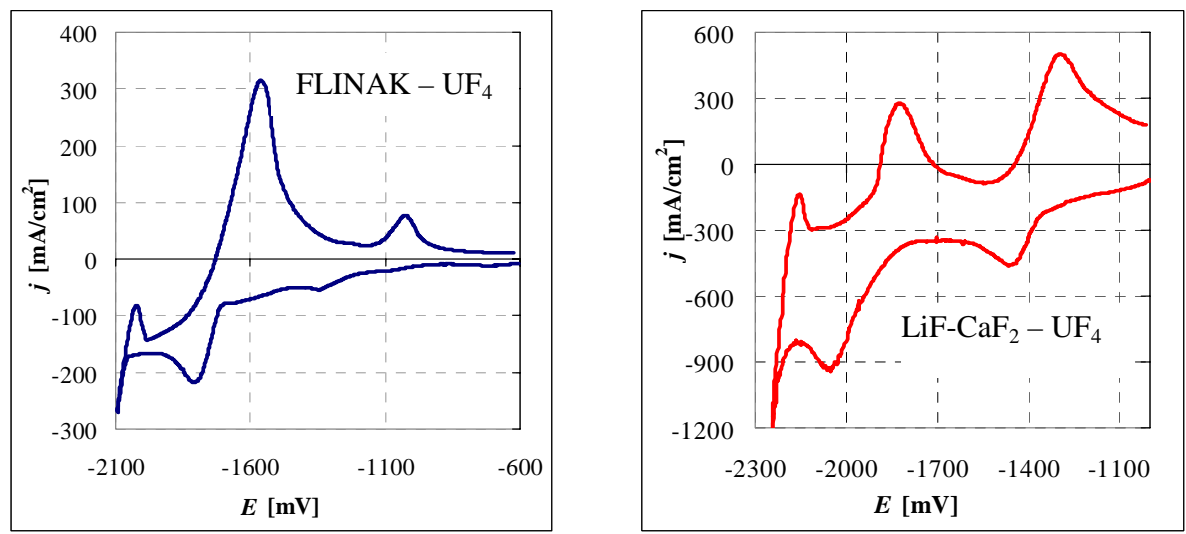

Fig. 3. Voltammograms of the systems FLINAK $-\mathrm{UF}_{4}$ and $\mathrm{LiF}_{-} \mathrm{CaF}_{2}-\mathrm{UF}_{4}$ (1.0 mol. \%) on Mo working electrode, scan rate $50 \mathrm{mV} / \mathrm{s}$.
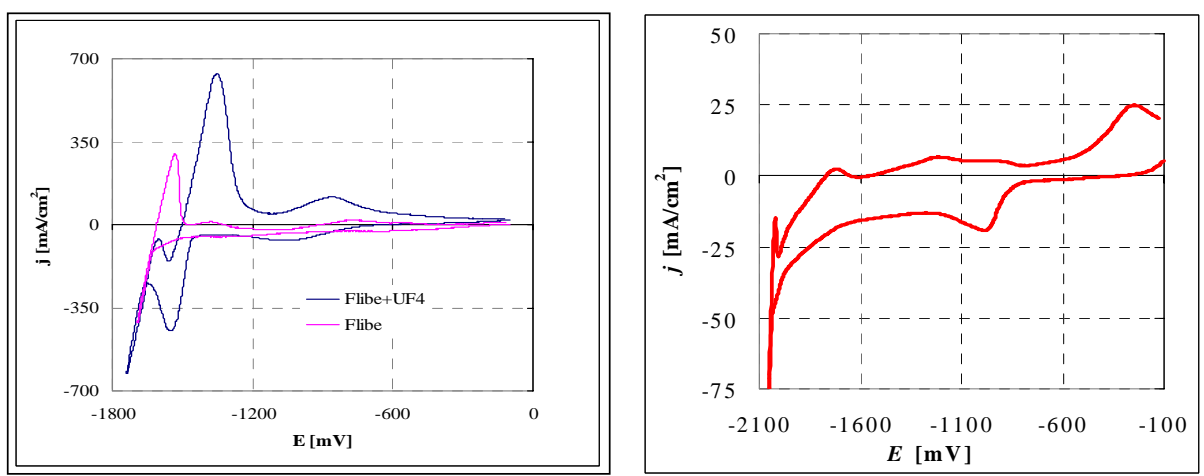

Fig. 4. Voltammograms of the system and FLIBE-UF4 (1.0 mol. \%, left) in comparison with pure FLIBE and FLINAK-ThF 4 (1.0 mol. \%, right) on Mo working electrode, scan rate $50 \mathrm{mV} / \mathrm{s}$. 


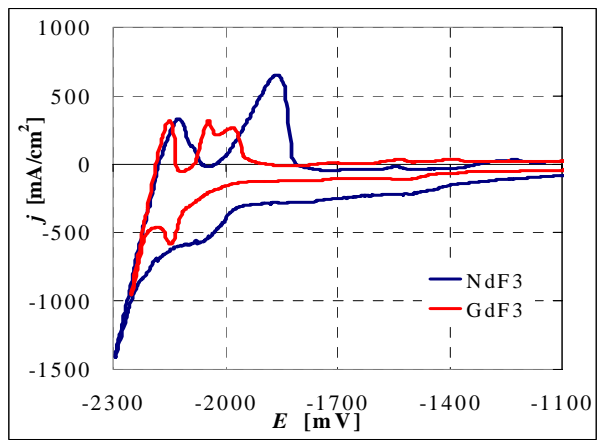

Fig. 5. Voltammograms of neodymium and gadolinium in $\mathrm{LiF}_{-} \mathrm{CaF}_{2}$ (1.0 mol. \%) on Mo working electrode; scan rate $50 \mathrm{mV} / \mathrm{s}$.

\section{EVALUATION}

This study is aimed at the appraisal of separation possibilities under conditions that are as close as possible to the real parameters of the future MSR reprocessing system. The separation possibilities of the studied elements were assessed by comparison of their deposition potentials with regard to the corresponding reaction mechanism. All presented red-ox potentials were evaluated from experimentally measured voltammograms using the graphical method. It was impossible to exactly determine the deposition potentials of neodymium and gadolinium in FLINAK and europium in $\mathrm{LiF}_{-} \mathrm{CaF}_{2}$, because their fluorides are more electrochemically stable than respective carrier melt constituents. The same results were found out also for lanthanum and praseodymium in FLINAK. For this reason, their unknown deposition potentials were substituted by the decomposition potential of the melt for purposes of comparison. The summary of evaluated red-ox potentials and reaction mechanisms are given in Table 1 . The assessed separation possibilities are summarized in Table 2. As the minimal potential difference for successful quantitative separation was considered $200 \mathrm{mV}$.
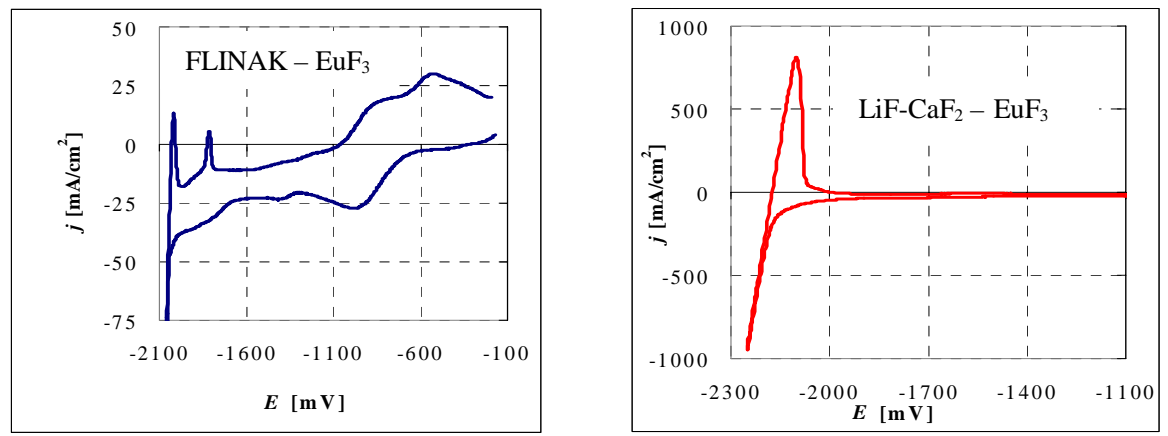

Fig. 6. Voltammograms of the systems FLINAK-EuF 3 and $\mathrm{LiF}-\mathrm{CaF}_{2}-\mathrm{EuF}_{3}$ $(1.0 \mathrm{~mol} . \%)$ on Mo working electrode; scan rate $50 \mathrm{mV} / \mathrm{s}$. 
Table I Red-ox potentials of studied elements in the melts FLINAK and $\mathrm{LiF}-\mathrm{CaF}_{2}$.

\begin{tabular}{|c|c|c|}
\hline & $\begin{array}{c}\text { FLINAK } \\
\text { E }[\mathrm{V}] \text { vs. } \mathrm{Ni} / \mathrm{Ni}^{2+} \text { in FLINAK }\end{array}$ & $\begin{array}{c}\text { LiF - CaF2 } \\
\text { E [V] vs. Ni/Ni }{ }^{2+} \text { in } \mathrm{LiF}-\mathrm{CaF} 2\end{array}$ \\
\hline Cathodic limit & $-2.05 \mathrm{~V}$ & $-2.30 \mathrm{~V}$ \\
\hline Uranium reduction & $\begin{array}{l}\text { Two-step reaction } \\
-1.20 \text { and }-1.75 \mathrm{~V}\end{array}$ & $\begin{array}{l}\text { Two-step reaction } \\
-1.40 \text { and }-1.85 \mathrm{~V}\end{array}$ \\
\hline Thorium reduction & $\begin{array}{l}\text { Two-step reaction } \\
-0.70 \text { and }-2.00 \mathrm{~V}\end{array}$ & Not measured \\
\hline $\begin{array}{l}\text { Neodymium } \\
\text { reduction }\end{array}$ & Not observed & $\begin{array}{c}\text { One-step reaction } \\
-2.00 \mathrm{~V}\end{array}$ \\
\hline $\begin{array}{l}\text { Gadolinium } \\
\text { reduction }\end{array}$ & Not observed & $\begin{array}{c}\text { One-step reaction } \\
-2.10 \mathrm{~V}\end{array}$ \\
\hline $\begin{array}{l}\text { Europium } \\
\text { reduction }\end{array}$ & $\begin{array}{l}\text { Two-step reaction } \\
-0.75 \text { and }<-1.95 \mathrm{~V}\end{array}$ & $\begin{array}{c}\text { One-step reaction } \\
<-2.30 \mathrm{~V}\end{array}$ \\
\hline $\begin{array}{l}\text { Lanthanum and } \\
\text { Praseodymium } \\
\text { reduction }\end{array}$ & Not observed & Not measured \\
\hline
\end{tabular}

\section{CONCLUSION}

Research and development of pyrochemical reprocessing technologies for MSR fuel cycle that is carried on in NRI Rez plc is following the Czech Partitioning and Transmutation Concept relying on Fluoride Volatility Method and electroseparations as its key components. The FVM technology enables the reprocessing of spent nuclear fuel from Light-Water Reactors and simplifies the process of fuel preparation for a Molten-Salt Transmutation Reactor. Its abilities are even to process other input material such as fast reactor oxide fuels and even advanced nuclear fuels like carbide or composite fuels that makes this technology ahead of currently industrially used methods. Electroseparations can be helpful both in preparation of MSTR fuel and reprocessing MSRs liquid fuels.

According to the results obtained so far from this study, electrochemical methods seem to be able to effect the separation of actinides from lanthanides in molten fluoride salts. However, for the particular application of the method within the "on-line" reprocessing of the MSR fuel, some important facts has to be taken into account. The lanthanides should be removed from the main fuel circuit of the MSR and the actinides should remain there to be further processed in the reactor core. This aim is impossible to accomplish by using studied technique of potentially-controlled electrolysis, because deposition potentials of the lanthanides are more negative in comparison with those of the actinides. The combination of a) pre-reduction of all presented elements, and b) the subsequent groupselective separation by the anodic dissolution method, is proposed as a 
solution to this problem. The outline of the flow sheet for the MSR fuel reprocessing is shown in Fig. 7.

Table 2. Summary of assessed separation possibilities of studied compounds

\begin{tabular}{|c|c|c|c|c|c|c|c|}
\hline \multirow{3}{*}{ FLINAK } & $\begin{array}{l}\text { Separated } \\
\text { elements }\end{array}$ & $\begin{array}{c}\mathrm{U}-\mathrm{Nd}, \mathrm{La}, \\
\mathrm{Pr}\end{array}$ & $\mathrm{U}-\mathrm{Gd}$ & $\mathrm{U}-\mathrm{Th}$ & $\mathrm{U}-\mathrm{Eu}$ & Th - Ln & $\begin{array}{c}\mathrm{Nd}, \mathrm{Gd}, \mathrm{La} \\
\mathrm{Pr}-\mathrm{Eu}\end{array}$ \\
\hline & $\begin{array}{l}\text { Potential } \\
\text { difference }\end{array}$ & $>300 \mathrm{mV}$ & $>300 \mathrm{mV}$ & $250 \mathrm{mV}$ & $200 \mathrm{mV}$ & $>50 \mathrm{mV}$ & $>100 \mathrm{mV}$ \\
\hline & $\begin{array}{l}\text { Separation } \\
\text { possibilities }\end{array}$ & yes & yes & yes & limit value & $\mathrm{n} / \mathrm{a}$ & $\mathrm{n} / \mathrm{a}$ \\
\hline \multirow{3}{*}{$\mathrm{LiF}-\mathrm{CaF}_{2}$} & $\begin{array}{l}\text { Separated } \\
\text { elements }\end{array}$ & $\mathrm{U}-\mathrm{Nd}$ & $\mathrm{U}-\mathrm{Gd}$ & U - Eu & $\mathrm{Nd}$ - Gd & $\mathrm{Nd}-\mathrm{Eu}$ & Gd - Eu \\
\hline & $\begin{array}{l}\text { Potential } \\
\text { difference }\end{array}$ & $150 \mathrm{mV}$ & $250 \mathrm{mV}$ & $\begin{array}{c}>450 \\
\mathrm{mV}\end{array}$ & $100 \mathrm{mV}$ & $\begin{array}{c}>300 \\
\mathrm{mV}\end{array}$ & $>200 \mathrm{mV}$ \\
\hline & $\begin{array}{l}\text { Separation } \\
\text { possibilities }\end{array}$ & no & yes & yes & no & yes & yes \\
\hline
\end{tabular}

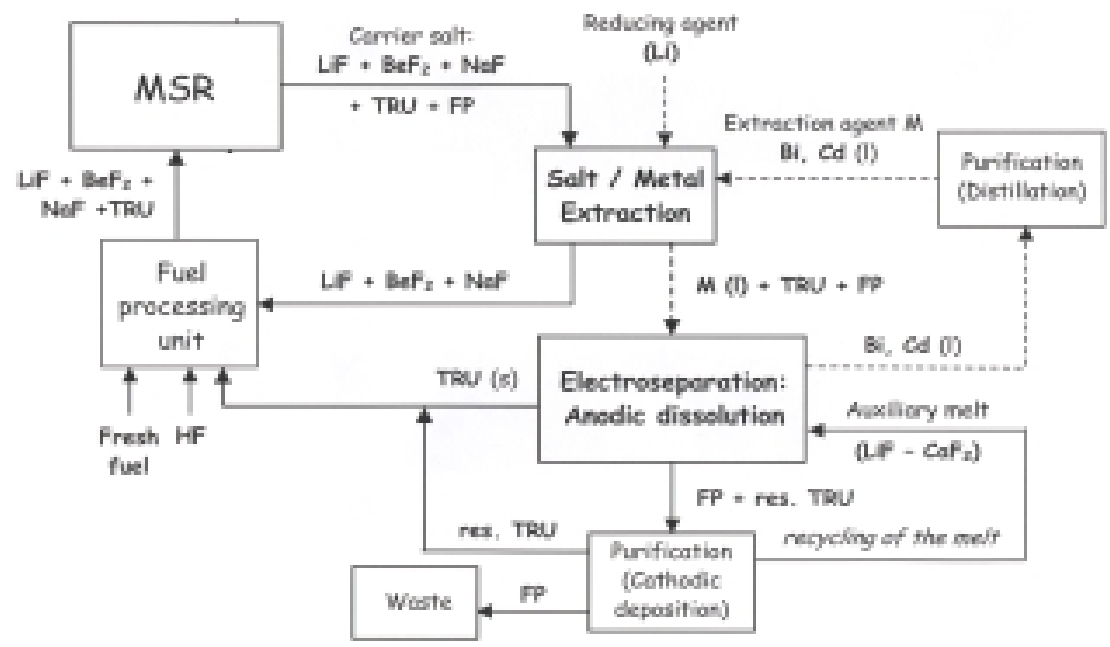

Fig. 7. Proposed flow sheet for MSR fuel reprocessing. 


\section{REFERENCES}

1. A Technology Roadmap for Generation IV Nuclear Energy Systems, US DOE, (2002)

2. HAUBENREICH, P. N. Molten-salt reactor progress, pages $325-329 \mathrm{v}$ Nuclear Engineering International, April (1969)

3. PRECEK, M. P/T - Fuel cycle of transmutation reactors, literature search work, Department of Nuclear Chemistry - Faculty of Nuclear Sciences and Physical Engineering of CTU, Praha (2004)

4. NAKAJIMA, T., GROULT, H. (editors), Fluorinated Materials for Energy Conversion, Chapter 24, Elsevier Ltd., (2005)

5. DOCEKAL, J., RICHTER,J. Flame fluorinator - introduction study, VUCHz Brno, (1977)

6. G. J. JANZ, R. P. T. CAROLYN, B. ALLEN, J. R. DOWNEY, JR. AND R. P. T. TOMKINS, Physical Properties Data Compilations Relevant to Energy Storage. I. Molten Salts: Eutectic Data, Nat. Stand. Ref. Data Ser., Nat. Bur. Stand. (U.S.), 61, Part I (1978)

7. H. W. JENKINS, G. MAMANTOV, D. L. MANNING, J. Electroanal. Chem, Vol. 19, p. 385 (1968)

8. H. R. BRONSTEIN, D. L. MANNING, Lanthanum Trifluoride as a Membrane in a Reference Electrode for Use in Certain Molten Fluorides, J. Electrochem. Soc.: Electrochemical Science and Technology, Vol. 119, 2, pp. 125 - 128 (1972) S

9. CLAYTON, F. R., G. MAMANTOV, D. L. MANNING, Electrochemical Studies of Uranium and Thorium in Molten LiF-NaF$K F$ at $500^{\circ} \mathrm{C}$, J. Electrochem. Soc, Vol. 121, 1, pp. 86 - 90 (1974)

10. U.S. DOE Nuclear Energy Research Advisory Committee at the Generation IV International Forum, A Technology Roadmap for Generation IV Nuclear Energy Systems, December (2002), GIF-002-00 